\title{
KOMPETENSI ACCOUNT OFFICER ANALISIS SYARIAH TERHADAP PERFORMANCE PEMBIAYAAN MUDHARABAH DENGAN RISIKO PEMBIAYAAN SEBAGAI INTERVENING (Studi pada Lembaga Keuangan Mikro Syariah se Pulau Lombok)
}

\author{
Kartika Silvia Purba \\ Animah \\ L. Takdir Jumaidi \\ Fakultas Ekonomi dan Bisnis, Universitas Mataram
}

\begin{abstract}
The objective of this study is to determine the influence of sharia account officers competence on the performance of mudharabah financing with the financing risk as intervening variable. Islamic microfinance institutions were selected as object of study in order to determine the extent of the theory related to the variables studied could be applied on the Islamic microfinance institutions. The data were obtained using a questionnaire distributed to the head of main office or branch office of sharia cooperative on the island of Lombok with requirements of sharia cooperative, BMT, boarding schools cooperative, and Islamic rural banks which had applied and have the authorization of mudharabah financing in lending decisions. The results showed that the sharia account officer competences have significant and negative influence on financial risk. Sharia officer competences also have significant and positive influence on the performance of financing. The results also showed that the risk of financing have significant and positive influence on the performance of financing. Generally, sharia account officer competence is important in minimizing the risk of financing and direct influence on the performance of financing. Thus, to improve the performance of Islamic micro financing with mudharabah can be done by increasing the competence of sharia account officer.
\end{abstract}

Keywords: Competence sharia officer account, the performance of financing, risk of financing 


\section{PENDAHULUAN}

Lembaga keuangan merupakan salah satu instrument penting dalam sistem ekonomi modern. Tidak satupun negara modern yang menjalankan kegiatan ekonominya tanpa melibatkan lembaga keungan baik itu perbankan ataupun non-perbankan. Persoalan muncul ketika terdapat sekelompok masyarakat muslim yang merasa sulit menerima kehadiran lembaga keuangan konvensional dalam kehidupannya, dikarenakan adanya unsur-unsur yang dinilai tidak sesuai dengan ajaran agamanya yaitu bunga. Menurut sebagian besar masyarakat muslim, sistem bunga sama dengan riba yang dilarang keras dalam Qur'an dan Sunnah (Muhammad, 2008).

Dengan situasi semacam itu, umat Islam menghadapi dilema yang cukup pelik. Disatu sisi mereka menyadari akan perlunya lembaga keuangan untuk menggairahkan kegiatan ekonomi yang berarti juga untuk meningkatkan kesejahteraan masyarakat, namun disisi lain mereka dihadapkan pada ajaran agama yang mengharuskan menghindari atau paling tidak membatasi keterlibatannya dengan lembaga keungan yang berbasis konvensional. Mengatasi dilema semacam ini, pelaku ekonomi Islam akhirnya menawarkan konsep keuangan yang sesuai dengan ajaran Islam yaitu dengan mekanisme bagi hasil atau system profit and loss sharing (PLS). Hal ini sesuai dengan pandangan Warde (2000) dan Mallat (2000) dikutip dari Muhammad (2008) bahwa mekanisme bagi hasil ini merupakan core produk bagi lembaga keuangan syariah. Sebab bank syariah secara eksplisit melarang penerapan tingkat bunga pada semua transaksi keuangannya. System loss and profit sharing (PLS) atau bagi hasil ini juga telah dipraktikan di Pakistan dan Malaysia sekitar tahun 1940-an, yakni dengan adanya upaya untuk mengelola dana jamaah haji secara nonkonvensional (Antonio, 2001:18).

Secara umum, prinsip bagi hasil dalam lembaga keuangan syariah dapat dilakukan dalam empat akad utama yaitu: al-musyarakah, almudharabah, al-muzaraah, dan mushaqah (Antonio,2001). Namun, yang banyak dipakai biasanya adalah al-musyarakah. Karim (2004) juga menyataka bahwa hampir semua bank syariah di dunia didominasi dengan produk pembiayaan murabahah, sedangkan sistem bagi hasil sangat sedikit diterapkan, kecuali di dua negara yaitu Iran (48\%) dan Sudan (62\%). Warde (1999:99) juga menyatakan bahwa perkembangan pembiayaan bagi hasil baru mencapai $15 \%$. Selain itu dari statistic perbankan syariah turut menyatakan bahwa pertumbuhan share keuangan syariah di Indonesia pada tahun 2013-2014 untuk pembiayaan mudharabah sebesar 8,7\%, pembiayaan musyarakah sebesar 23,9\%, dan pembiayaan murabahah sebesar $67,4 \%$.

Rendahnya pembiayaan mudharabah cenderung merupakan masalah yang multi dimensi yang telah terjadi sejak lama dan tidak ada kecenderungan untuk berubah. Implikasi dari tingginya pembiayaan non 
bagi-hasil (seperti murabahah) adalah terbentuknya persepsi publik bahwa perbankan syariah hampir tidak ada bedanya dengan perbankan konvensional. Persepsi yang demikian akan membentuk suatu resiko reputasi tersendiri yang dikhawatirkan akan menimbulkan sinisme di kalangan masyarakat bahwa bisnis keuangan yang berbasis syariah hanya merupakan pergantian nama saja sedangkan mindset pelakunya tetaplah umum (Muhammad, 2008).

Sekalipun pembiayaan mudharabah sudah mendapat tempat di kalangan masyarakat muslim pada umumnya, tetapi ternyata kinerja dari pembiayaan mudharabah itu sendiri masih dipertanyakan. Dalam kenyatannya masih terdapat kendala yang ditemui dalam penerapannya. Seperti yang dinyatakan oleh Warde (1999:199) bahwa Bank Syariah berkeinginan mengembangkan produk pembiayaan bagi hasil (mudharabah) tersebut, tetapi kondisi masyarakat belum menyediakan iklim yang diinginkan.

Kesenjangan antara teori dan realita sebenarnya, tentu di pengaruhi oleh faktor-faktor tertentu. Tetapi, peneliti beranggapan bahwa permasalahan pembiayaan mudharabah lebih didominasi dari faktor manajemen suatu lembaga keuangan tersebut. Seperti yang dinyatakan oleh Emmyah (2009) jika kompetensi karyawan, mempunyai pengaruh yang kuat terhadap kinerja sebuah organisasi. Berangkat dari permasalahan diatas, akhirnya peneliti tertarik untuk meneliti kinerja dari pembiayaan mudarabah dengan melihat variabel-variabel yang dianggap mempunyai hubungan pengaruh langsung dan tidak langsung dengan kinerja pembiayaan mudharabah tersebut.

Variabel langsung yang diduga mempengaruhi kinerja pembiayaan mudharabah adalah kompetensi account officer syariah. Kompetensi adalah pengetahuan, skill dan kemampuan serta karakter yang berhubungan dengan kinerja efektif yang tinggi. Menurut Karim (2004a:251) resiko pembiayaan bisa timbul karena analisis pembiayaan yang keliru dilakukan karyawan lembaga keuangan syariah. Untuk mengurangi resiko ini, lembaga keungan memerlukan staf yang terlatih dan berpengalaman. Selain terkait dengan resiko, kompetensi juga merupakan salah satu penentu kinerja. Hasil penelitian Yumanita (2005) menyimpulkan bahwa rendahnya pembiayaan sistem bagi hasil mudharabah disebabkan oleh kurangnya sumber daya insani. Samad dan Hassan (1999) dalam jurnalnya yang berjudul The Performance of Malaysian Islamic Bank During 1984-1997, yang menunjukkan bahwa pembiayaan berdasarkan sistem profit sharing and joint venture profit sharing tidak populer di Malaysia disebabkan karena hampir 40\% s/d 70\% account officer kurang pengetahuan dalam menyeleksi proyek atau bisnis bagi hasil yang menguntungkan, mengelola bisnis bagi hasil dan mengevaluasi tingkat keuntungan dari suatu bisnis.

Selain itu, variabel yang diduga dapat berpengaruh tidak langsung 
terhadap kinerja pembiayaan mudharabah adalah melalui risiko pembiayaan mudharabah. Pada dasarnya, setiap organisasi baik itu dari lembaga keuangan konvensional ataupun syariah tidak terlepas dari risikorisiko yang dihadapi dalam bisnis yang ditawarkan. Hukum bisnis mengatakan "tidak ada return tanpa risiko". Menilik hal demikian, pelaku bisnis syariah selalu berupaya mendapatkan bisnis yang memiliki return tinggi dengan risiko minimal. Semakin kecil risiko yang dihadapi atau dijumpai dalam suatu bisnis, diduga kinerjanya akan semakin baik.

Oleh sebab itu, peneliti terdorong untuk melakukan penelitian terkait dengan kinerja pembiayaan mudharabah. Hal ini guna mendapatkan hasil, apakah variabel yang telah disebutkan diatas benar-benar mempengaruhi kinerja pembiayaan mudharabah atau tidak dengan populasi dan sampel seluruh lembaga keuangan mikro syariah yang tersebar di Pulau Lombok. Diharapkan dengan ditemukannya variabel yang berpengaruh terhadap pembiayaan mudharabah, seluruh lembaga keuangan mikro syariah yang menggunakan sistem pembiayaan mudharabah di Pulau Lombok dapat lebih meningkatkan kinerja pembiayaan mudharabah yang diterapkannya.

\section{THEORETICAL FRAMEWORK AND HYPOTHESIS DEVELOPMENT}

\section{Lembaga Keuangan}

\section{a. Bank Syariah}

Bank Syariah adalah bank yang beroperasi dengan tidak mengandalkan pada bunga serta dapat diartikan sebagai lembaga keuangan yang operasionalnya dikembangkan berlandaskan Al-Qur'an dan Hadis Nabi Muhammad SAW. Arifin (2009:3) berpendapat bahwa bank syariah didirikan dengan tujuan untuk mempromosikan dan mengembangkan dasar prinsip-prinsip syariah Islam dan tradisinya ke dalam transaksi keuangan dan perbankan serta bisnis lainnya yang terkait. Prinsip utama yang diikuti oleh bank Islam yaitu:

1. Larangan riba dalam berbagai bentuk transaksi,

2. Melakukan kegiatan usaha dan perdagangan berdasarkan perolehan keuntungan yang sah menurut Islam,

3. Memberikan zakat.

\section{b. Lembaga Keuangan Mikro Syariah}

Lembaga keuangan mikro menurut Undang-Undang nomor 1 tahun 2013 adalah lembaga keuangan yang khusus didirikan untuk memberikan jasa pengembangan usaha dan pemberdayaan masyarakat, baik melaui pinjaman atau pembiayaan dalam usaha skala mikro kepada anggota dan masyarakat, pengelolaan simpanan, maupun pemberian jasa konsultasi pengembangan usaha yang tidak semata-mata mencari keuntungan.

Lembaga Keuangan Mikro syariah (LKMS) terdiri dari berbagai lembaga diantaranya BPRS (Bank Perkreditan Mikro Syariah), BMT (Baitul 
Mal Wat Tanmil), serta Koperasi Syariah. (www.zanikhan.multiply.com). Ketiga lembaga tersebut mempunyai hubungan yang erat dan saling mempengaruhi satu sama lain dan berhubungan erat dengan lembaga syariah lainnya yang lebih besar seperti bank syariah. Menurut Muhammad (2000:25) Lembaga keuangan syariah itu sendiri telah mengelola berjuta bahkan bermiliar rupiah dana masyarakat sesuai dengan prinsip syariah.

\section{Prinsip-prinsip Lembaga Keuangan Syariah}

Menurut Muhammad (2000:25) prinsip-prinsip lembaga keuangan syariah adalah:

1. Larangan menerapkan bunga pada semua bentuk dan jenis transaksi;

2. Menjalankan aktivitas bisnis dan perdagangan berdasarkan pada kewajaran dan keuntungan yang halal;

3. Mengeluarkan zakat dari hasil kegiatannya;

4. Larangan menjalankan monopoli;

5. Bekerjasama dalam membangun masyarakat, melalui aktivitas bisnis dan perdagangan yang tidak dilarang oleh Islam.

\section{Landasan Hukum Perbankan Syariah}

Dalam hukum bisnis syariah, untuk menentukan halal haramnya suatu transaksi harus mengacu pada ketentuan hukum syariat yang bersumber pada Al-Qur'an dan Hadits. Menurut ketentuan syari'at, sistem bunga bank (interest) adalah sama dengan riba yang haram hukumnya, sebagaimana disebutkan dalam Al-Qur'an yang artinya.

"dan sesuatu Riba (tambahan) yang kamu berikan agar Dia bertambah pada harta manusia, Maka Riba itu tidak menambah pada sisi Allah. dan apa yang kamu berikan berupa zakat yang kamu maksudkan untuk mencapai keridhaan Allah, Maka (yang berbuat demikian) Itulah orangorang yang melipat gandakan (pahalanya)." (QS.Ar-Rum:39)

Bukan hanya bersumber dari Qur'an, landasan hukum lembaga keuangan syariah baik itu bank syariah dan lembaga keungan non-bank juga telah diatur dalam UU yaitu pada Undang-undang Nomor 7 Tahun 1992 sebagai landasan hukum bank dan Peraturan Pemerintah Nomor 72 Tahun 1992 tentang Bank Umum berdasarkan prinsip bagi hasil sebagai landasan hukum Bank Umum Syariah dan Peraturan Pemerintah Nomor 73 tentang Bank Perkreditan Rakyat berdasarkan prinsip bagi hasil sebagai landasan hukum Bank Perkreditan Rakyat Syariah. Sesuai dengan perkembangan perbankan maka Undang-undang Nomor 7 tahun 1992 tentang perbankan disempurnakan dengan Undang-undang Nomor 10 tahun 1998 tentang Perubahan Undang-undang Nomor 7 tahun1992 tentang perbankan dan juga tercakup hal-hal yang berkaitan dengan perbankan syariah. 


\section{Kontrak Mudharabah}

Dalam fikih mu'amalah, Mudharabah dinamakan juga dengan Qiradh, yaitu bentuk kerja sama antara pemilik modal (shohibul mal/rabbul mal) dengan pengelola (mudharib) untuk melakukan usaha dimana keuntungan dari usaha tersebut dibagi diantara kedua pihak tersebut, dengan rukun dan syarat tertentu. Mudharabah menurut bahasa diambil dari bahasa arab yaitu dharb, maksudnya Adharbu fil ardhi yaitu bepergian untuk berurusan dagang, sebagaimana Allah berfirman dalam surat Al Mujammil ayat 20 yang artinya:

"Dan yang lainnya bepergian dimuka bumi mencari karunia dari Allah". (QS. 73: 20 ).

Menurut pandangan ulama ahli fiqih (fuqaha) Mudharabah adalah akad antara kedua belah pihak dimana salah seorangnya mengeluarkan sejumlah uang kepada pihak lainnya untuk diperdagangkan dan laba dibagi sesuai dengan kesepakatan. Ulama madzhab Syafi'i mendefenisikan Mudharabah adalah sebagai berikut:

"Mudharabah adalah akad (transaksi) antara dua orang atau lebih, diantara yang satu menyerahkan harta atau modal kepada pihak kedua untuk dijalankan usaha, dan masing-masing mendapatkan keuntungan dengan syarat-syarat tertentu"

Akad mudharabah diperbolehkan dalam Islam karena bertujuan untuk saling membantu antara pemilik modal dan seseorang yang ahli dalam memutarkan uang (usaha/dagang). Mudharib sebagai entrepreneur adalah sebagian dari orang-orang yang melakukan perjalanan untuk mencari karunia dan ridha Allah. Firman Allah dalam Qur'an surah AlJum'ah ayat 10 yang artinya:

"apabila telah ditunaikan shalat, maka bertebaranlah kamu dimuka bumi dan carilah karunia Allah dan ingatlah Allah sebanyakbanyaknya agar kamu beruntung (QS Al-Jum'ah:10)"

\section{Kompetensi Account officer Syariah}

Account officer merupakan aparat atau pegawai perbankan yang menawarkan produk bank kepada nasabah dimana salah satu produk yang ditawarkan adalah produk pembiayaan. Seorang account officermempunyai tugas ganda yaitu sebagai personil bank atau aparat bank yang harus bekerja dibawah peraturan dan keinginan atau tujuan bank dan di sisi lain account officer harus memberikan yang terbaik kepada nasabah (rivai dan veithzal, 2008). Sebagai seorang account officer yang mempunyai peranan cukup penting bagi kelangsungan hidup perbankan, sehingga kompetensi seorang account officer juga harus diperhitungkan.

Wei and Weidong (2002) menjelaskan bahwa kompetensi adalah pengetahuan, skill dan kemampuan serta karakter yang berhubungan 
dengan kinerja efektif yang tinggi. Kompetensi mempunyai pengaruh nyata terhadap kinerja. Ismail (2001) mengungkapkan bahwa secara empirik hubungan yang signifikan antara sumber daya manusia dengan pengukuran kinerja baik pada perusahaan yang berbasis pengetahuan tinggi maupun rendah. Riset yang dilakukan oleh Iqbal (2001) menyimpulkan bahwa skill yang tinggi sangat dibutuhkan dalam menangani bermacam-macam dan kompleknya transaksi pembiyaan. Menurut Ibrahim (2004) rendahnya pengembangan bank Islam disebabkan karena ketiadaan keahlian sumber daya manusia di perbankan syariah.

\section{Risiko Pembiayaan Mudharabah}

Menurut Soemarno, risiko ialah suatu kondisi yang timbul karena ketidakpastian dengan seluruh konsekuensi tidak menguntungkan yang mungkin terjadi (ngapackers.blogspot.com). Bank Indonesia (2002) mengungkapkan bahwa rendahnya pembiayaan sistem bagi-hasil disebabkan oleh resiko investasi relatif tinggi. Isu krisis likuiditas disebabkan ketidakmampuan bank membiayai kenaikan aset dan memenuhi kewajiban jatuh tempo dapat menyebabkan mulai dari kerugian dalam profitabilitas sampai dengan bangkrut secara total.

Menurut Arifin (2006:121) manajemen bank harus secara simultan mempertimbangkan berbagai resiko yang akan berpengaruh pada perubahan tingkat laba yang diperoleh. Karena resiko kredit, terjadi ketidakpastian net- income dan market value of equity disebabkan karena tidak ada pembayaran dan penundaan pembayaran baik pokok maupun bunga (Ahmed:2005). El-Biraika (2001) menjelaskan bahwa sistem bagihasil meningkatkan finance stability melalui pengurangan resiko dan mengeliminasi konflik kepentingan antara peminjam dan pemberi pinjaman membuat perbankan Islam lebih efisien sebagai lembaga intermediasi.

\section{Kinerja Pembiayaan Mudharabah}

Kinerja merupakan suatu fungsi dari motivasi dan kemampuan untuk menyelesaikan tugas atau pekerjaan. Seseorang sepatutnya memiliki derajat kesediaan dan tingkat kemampuan tertentu. Kesediaan dan keterampilan seseorang tidaklah cukup efektif untuk mengerjakan sesuatu tanpa pemahaman yang jelas tentang apa yang akan dikerjakan dan bagaimana mengerjakan. Kinerja merupakan perilaku nyata yang ditampilkan setiap orang sebagai prestasi kerja yang dihasilkan oleh pegawai sesuai dengan perannya dalam perusahaan. Kinerja merupakan suatu hal yang sangat penting dalam upaya perusahaan untuk mencapai tujuan. Perusahaan umumnya mendasarkan perencanaan tujuan yang hendak dicapai di masa depan.

Efendy (2002:194) mengatakan bahwa Kinerja adalah unjuk kerja yang merupakan hasil kerja dihasilkan oleh pegawai atau prilaku nyata yang ditampilkan sesuai dengan perannya dalam organisasi. Sedangkan menurut Bernadin dan Russel yang dikutip Faustino (2000;135) Kinerja 
adalah outcome yang dihasilkan dari fungsi suatu pekerjaan tertentu atau kegiatan selama satu periode tertentu. Melalui kinerja yang baik, tentunya sebuah bisnis juga akan berjalan dengan baik. Sehingga kinerja pembiayaan mudharabah didefinisikan sebagai hasil kerja yang dapat dicapai produk pembiayaan mudharabah. Semakin baik kinerja pegawai, maka pencapaian produk pembiayaan mudharabah juga semakin baik.

\section{Perumusan Hipotesis}

Berdasarkan tinjauan pustaka dan kerangka berfikir diatas, maka dapat ditarik hipotesis awal sebagai berikut:

H1: Diduga kompetensi account officer syariah berpengaruh signifikan terhadap kinerja pembiayaan mudharabah. H2: Diduga kompetensi account officer syariah berpengaruh signifikan terhadap resiko pembiayaan mudharabah. H3: Diduga resiko pembiayaan mudharabah berpengaruh signifikan terhadap kinerja pembiayaan mudharabah.

\section{RESEARCH METHOD (METODOLOGI PENELITIAN)}

\section{Pengumpulan Data}

Penelitian ini menggunakan pendekatan kuantitatif untuk menguji variabel kompetensi account officer syariah dan resiko pembiayaan mudharabah terhadap kinerja pembiayaan mudharabah, pada Lembaga Keuangan Mikro Syariah se-Pulau Lombok. Data diperoleh berdasarkan pandangan, tanggapan, persepsi atau penilaian dari pimpinan pembiayaan mudharabah kantor pusat koperasi syariah, BMT dan kapontren (Koperasi Pesantren) yang ada di Pulau Lombok terhadap variabel-variabel yang diteliti.

Populasi dalam penelitian ini adalah lembaga keuangan mikro syariah baik itu Bank Perkreditan Rakyat Syariah (BPRS) koperasi syariah, BMT atau Kapontren di Pulau Lombok yang berjumlah 36 kantor Lembaga Keuangan Mikro Syariah, dengan responden yakni pimpinan dari lembaga keuangan mikro syariah.

Data lembaga keuangan mikro syariah yang terdapat di pulau Lombok dari Dinas Koperasi masing-masing kabupaten:

Tabel 1 Lembaga Keuangan Mikro di Lombok

\begin{tabular}{|c|l|l|}
\hline No & Nama Lembaga Keuangan Mikro & \multicolumn{1}{c|}{ Alamat } \\
\hline 1 & Koperasi produsen syariah mandiri & Lombok Timur \\
\hline 2 & Kapontren al-mukhlisin & Lombok Timur \\
\hline 3 & KSU BMT al-hidayah & Lombok Timur \\
\hline 4 & KJKS BMT barokah mandiri & Lombok Timur \\
\hline 5 & Kapotren Azma & Lombok Timur \\
\hline 6 & KSU syariah mandiri & Lombok Timur \\
\hline 7 & KSU permata syariah & Lombok Timur \\
\hline
\end{tabular}




\begin{tabular}{|c|l|l|}
\hline 8 & BMT al-ikhlas & Lombok Timur \\
\hline 9 & KJKS surya abadi & Lombok Timur \\
\hline 10 & BMT Nazir waqaf paguyuban masjid & Lombok Timur \\
\hline 11 & KJKS akta salum & Lombok Timur \\
\hline 12 & Kapontren Nurussalam & Lombok Timur \\
\hline 13 & Darussolihin kalijaga & Lombok Timur \\
\hline 14 & BMT Ta'awun & Lombok Timur \\
\hline 15 & KSP nurul hakim & Lombok Timur \\
\hline 16 & BMT al-irsyad & Lombok Timur \\
\hline 17 & BMT al-hidayah & Lombok Timur \\
\hline 18 & Koperasi Syariah BMT Ar-Rasyada & Lombok Timur \\
\hline 19 & KSP BMT as-syaff & Lombok Tengah \\
\hline 20 & Kapontren Muhajirin & Lombok Tengah \\
\hline 21 & Kapontren al-mashudin & Lombok Tengah \\
\hline 22 & Kapontren manhalul ma'rif & Lombok Tengah \\
\hline 23 & Kapontren darul ulum & Lombok Tengah \\
\hline 24 & Kapontren Darussalam & Lombok Tengah \\
\hline 25 & Kapontren Nurul hakim & Lombok Barat \\
\hline 26 & Kapontren al-aziziah & Lombok Barat \\
\hline 27 & Kapontren akhlakul amin & Lombok Barat \\
\hline 28 & Kapotren Qomarul Huda & Lombok Barat \\
\hline 29 & Kapontren Tarbiatul Mustafit & Lombok Barat \\
\hline 30 & Kapontren Darrun nazah & Lombok Barat \\
\hline 31 & Koperasi BMT al-Muntadah & Mataram \\
\hline 32 & KSP BMT Gumarang akbar syariah & Mataram \\
\hline 33 & KSU al-iqtishady & Mataram \\
\hline 34 & BPRS Patuh Beramal & Mataram \\
\hline 35 & BPRS Dinar Asri & Mataram \\
\hline 36 & BPRS Tulen Amanah & Lombok Timur \\
\hline & & \\
\hline
\end{tabular}

\section{Klasifikasi Variabel dan Pengukurunnya}

Variabel-variabel yang dianalisis dalam penelitian ini diklasifikasikan dan diukur seperti berikut.

1. Kompetensi account officer syariah disingkat KAOS sebagai variabel independen yang pertama (X1);

2. Resiko pembiayaan mudharabah disingkat RPM sebagai variabel independen yang kedua $(\mathrm{X} 2)$.

3. Kinerja pembiayaan mudharabah disingkat KPM sebagai variabel dependen yang dipengaruhi oleh kompetensi account officer syariah, dan resiko pembiayaan mudharabah. 


\section{Metode Analisis Data}

Analisis data yang digunakan dalam penelitian ini adalah metode regresi linier sederhana menggunakan program SPSS dengan tingkat signifikasi $5 \%$. Adapun formula dari model regresi linier sederhana yang akan digunakan adalah:

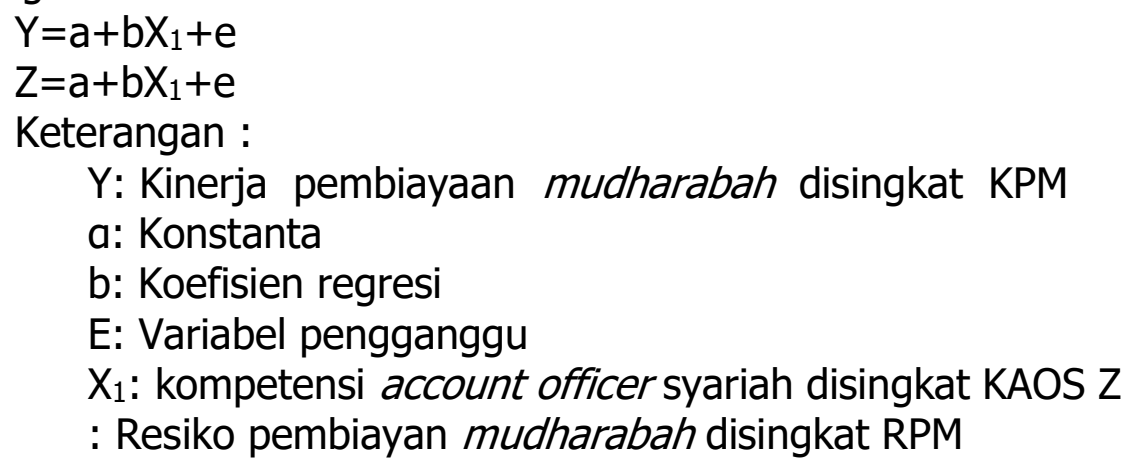

Setelah analisis linier sederhana dilakukan aalisis jalur, yaitu perluasan dari analisis regresi linear berganda atau analisis regresi untuk menaksir hubungan kausalitas antar variabel (Ghozali, 2005). Dalam penelitian ini, analisis jalur digunakan untuk memediasi antara variabel independent $X 1$ terhadap variabel dependent $Y$ menggunakan variabel $Z$. Adapun formula dari model analisis jalur yang akan digunakan sesuai adalah sebagai berikut:

$$
Y=a+b \cdot X_{1}+b \cdot X_{1} \times b \cdot Z+e
$$

HASIL

\section{Uji Hipotesis dan Pembahasan}

\section{a. Uji Validitas}

Tabel 2 Uji Validitas Data

\begin{tabular}{|l|l|l|}
\hline \multicolumn{1}{|c|}{ Variabel } & Indikator & R hitung \\
\hline \multirow{4}{*}{$\begin{array}{l}\text { Resiko pembiayaan } \\
\text { mudharabah }\end{array}$} & Indikator 1 & 0.400 \\
\cline { 2 - 3 } & Indikator 2 & 0.362 \\
\cline { 2 - 3 } & Indikator 3 & 0.363 \\
\cline { 2 - 3 } & Indikator 4 & 0.327 \\
\cline { 2 - 3 } & Indikator 5 & 0.321 \\
\cline { 2 - 3 } & Indikator 6 & 0.343 \\
\cline { 2 - 3 } Kompetensi account & Indikator 7 & 0.330 \\
\cline { 2 - 3 } officer & Indikator 8 & 0.341 \\
\cline { 2 - 3 } & Indikator 9 & 0.441 \\
\hline & Indikator 1 & 0.442 \\
\cline { 2 - 3 } & Indikator 2 & 0.464 \\
\cline { 2 - 3 } & Indikator 3 & 0.426 \\
\cline { 2 - 3 } & Indikator 4 & 0.340 \\
\cline { 2 - 2 } & & \\
\hline \multirow{4}{*}{}
\end{tabular}




\begin{tabular}{|c|c|c|}
\hline & Indikator 5 & 0.448 \\
\hline & Indikator 6 & 0.423 \\
\hline & Indikator 7 & 0.338 \\
\hline & Indikator 8 & 0.382 \\
\hline & Indikator 9 & 0.360 \\
\hline & Indikator 10 & 0.402 \\
\hline & Indikator 1 & 0.683 \\
\hline & Indikator 2 & 0.813 \\
\hline & Indikator 3 & 0.341 \\
\hline Kinerja & Indikator 4 & 0.339 \\
\hline & Indikator 5 & 0.460 \\
\hline & Indikator 6 & 0.320 \\
\hline & Indikator 7 & 0.341 \\
\hline
\end{tabular}

Dari tabel hasil uji validitas diatas memperlihatkan nilai $r$ hitung setiap indikator variabel kompensasi, motivasi dan kinerja $>0,30$. Dengan demikian indikator atau kuesioner yang digunakan oleh masing-masing variabel kompensasi, motivasi dan kinerja dinyatakan valid untuk digunakan sebagai alat ukur variabel.

\section{b. Uji Reliabilitas}

Tabel 3 Hasil Uji Reliabilitas

\begin{tabular}{|l|l|l|l|}
\hline & $\boldsymbol{X}_{\mathbf{1}}$ & $\boldsymbol{X}_{\mathbf{2}}$ & $\boldsymbol{Y}$ \\
\hline Nilai Cronbach's Alpha & 0,697 & 0,602 & 0,705 \\
\hline Keterangan & RELIABEL & RELIABEL & RELIABEL \\
\hline
\end{tabular}

Tabel di atas menunjukkan bahwa nilai cronbach's alpha yang terdiri dari variabel kompetensi $\left(X_{1}\right)$ sebesar 0,697 , variabel intervening resiko pembiayaan $\left(X_{2}\right)$ sebesar 0,602 , dan variabel kinerja pembiayaan $(Y)$ sebesar 0,705 artinya bahwa semua variabel memberikan nilai cronbach's alpha > 0,60 (Ghozali, 2005:42). Artinya semua variabel di atas reliabel.

\section{c. Uji Kolmogorov Smirnov}

Tabel 4 Uji Asumsi Normalitas Kolmogorov Smirnov

\begin{tabular}{|l|l|}
\hline \multicolumn{1}{|c|}{ Keterangan } & Unstandardized Residual \\
\hline $\mathrm{N}$ & 36 \\
\hline Kolgomorov-Smirnov Z & 0.850 \\
\hline Asymp. Sig. (2-tailed) & 0.465 \\
\hline & \\
\hline
\end{tabular}


Nilai kolmogorov-smirnov sebesar 0,850 dan hasil signifikansi berada diatas 0,05 . Sehingga, dapat disimpulkan bahwa residual terdistribusi secara normal atau dengan kata lain residual berdistribusi normal.

\section{d. Uji Heteroskedastisitas}

Tabel 5 Hasil Uji Heteroskedastisitas

\begin{tabular}{|l|l|}
\hline Variabel Independen & Sig. \\
\hline Kompetensi & 0,363 \\
\hline Resiko & 0,360 \\
\hline
\end{tabular}

Berdasarkan Tabel 5 di atas dapat disimpulkan bahwa pada model regresi tidak terjadi heteroskedastisitas. Hal ini terlihat dari taraf signifikansi ketiga variabel independen yaitu di atas $5 \%(0,05)$, dengan kata lain pada model regresi terjadi kesamaan varian dari residual satu pengamatan ke pengamatan yang lain. Dengan demikian dapat disimpulkan bahwa model regresi ini tidak terjadi heteroskedastisitas.

\section{e. Analisis Regresi sederhana kompetensi terhadap kinerja}

Dari hasil analisis regresi linier sederhana menggunakan program SPSS 16.0 for Windows, diperoleh hasil sebagai berikut :

Tabel 6 Regresi sederhana kompetensi terhadap kinerja

\begin{tabular}{|l|l|l|l|l|l|}
\hline \multirow{2}{*}{ Variabel } & Unstnd.Coef. & $\begin{array}{l}\text { Standar } \\
\text { error }\end{array}$ & & & \\
& (B) & & Sig. & Keterangan \\
\hline (constant) & 7.794 & 5.722 & 1.362 & 0.005 & \\
\hline Kompetensi & 0.363 & 0.146 & 2.484 & 0.018 & Signifikan \\
\hline
\end{tabular}

$$
\begin{gathered}
\text { Adjusted } \mathrm{R}^{2} \text { Square }=0,129 \\
\mathrm{e}=0,805
\end{gathered}
$$

Berdasarkan perhitungan analisis regresi sederhana di atas, diketahui bahwa besarnya R Adjusted Square adalah 0,129. Hal ini berarti $12,9 \%$ variasi naik turunnya kinerja pembiayaan mudharabah bisa dijelaskan oleh variasi dari variabel independen (Kompetensi). Sedangkan sisanya $(100 \%-12,9 \%=87,1 \%)$ dijelaskan oleh sebab-sebab yang lain diluar model penelitian. Berdasarkan dari nilai Adjusted R Square dapat diartikan pula kompetensi mampu mempengaruhi kinerja sebesar $12,9 \%$. Di dalam perhitungan ini juga terdapat standar error (e) sebesar 0,805 yang artinya kemungkinan kesalahan estimasi atau perhitungan dalam penelitian ini sebesar 0,805.

Berdasarkan hasil analisis di atas, maka dapat disusun persamaan regresi sebagai berikut: 


$$
Y=0,363 X 1+0,805
$$

Berdasarkan persamaan regresi di atas, maka dapat dijelaskan sebagai berikut:

1. Koefisien regresi kompetensi bernilai positif sebesar 0,363 , hal ini menunjukkan kompetensi berpengaruh positif dan signifikan terhadap kinerja, sehingga adanya peningkatan kekampuan kompetensi account officer syariah akan meningkatkan kinerja pembiayaan mudharabah. Setiap terjadi peningkatan satu satuan Kompetensi akan menyebabkan peningkatan kinerja 0,363 dengan asumsi variabel independent lain konstan.

\section{Uji Signifikansi}

Berdasarkan hasil pengujian secara parsial dapat diketahui bahwa: Berdasarkan tabel 6 di atas dapat diketahui bahwa tingkat signifikansi dari variabel Kompetensi terhadap variabel kinerja pembiayaan yaitu sebesar 0,018 . Angka ini lebih kecil dari taraf signifikan 0,05. Hal ini menjelaskan bahwa variabel Kompetensi memiliki pengaruh terhadap variabel kinerja. Dengan demikian, maka hipotesis 1 dalam penelitian ini yang menyatakan bahwa Kompetensi account officer syariah berpengaruh terhadap kinerja pembiayaan mudharabah diterima.

\section{f. Analisis Regresi Sederhana Kompetensi terhadap Risiko}

Tabel 7 Regresi sederhana kompetensi terhadap resiko

\begin{tabular}{|l|l|l|c|l|l|}
\hline \multicolumn{1}{|c|}{ Variabel } & $\begin{array}{l}\text { Unstnd.Coef. } \\
\text { (B) }\end{array}$ & $\begin{array}{l}\text { Standar } \\
\text { error }\end{array}$ & T & Sig. & Keterangan \\
\hline (Constant) & 57.333 & 2.645 & 21.678 & 0.000 & \\
\hline Kompetensi & -.906 & .068 & -13.406 & 0.000 & Signifikan \\
\hline
\end{tabular}

Adjusted $\mathrm{R}^{2}$ Square $=0,836$

$$
\mathrm{e}=0,372
$$

Berdasarkan perhitungan analisis regresi berganda di atas, diketahui bahwa besarnya R Adjusted Square adalah 0,836. Hal ini berarti $83,6 \%$ variasi naik turunnya kinerja pembiayaan mudharabah bisa dijelaskan oleh variasi dari variabel independen (kompetensi account officer). Sedangkan sisanya $(100 \%-83,6 \%=16,4 \%)$ dijelaskan oleh sebab-sebab yang lain diluar model penelitian. Berdasarkan dari nilai Adjusted R Square dapat diartikan pula kompetensi mampu mempengaruhi resiko sebesar $83,6 \%$. Di dalam perhitungan ini juga terdapat standar error (e) sebesar 0,372 yang artinya kemungkinan kesalahan estimasi atau perhitungan dalam penelitian ini sebesar 0,372 .

Berdasarkan hasil analisis di atas, maka dapat disusun persamaan regresi sebagai berikut : $\mathrm{Y} 1=-0,906 \mathrm{X} 1+0,372$.

Berdasarkan persamaan regresi di atas, maka dapat dijelaskan 
sebagai berikut:

1. Koefisien regresi kompetensi bernilai Negatif sebesar - 0,906, hal ini menunjukkan kompentensi berpengaruh sercara terbalik, sehingga adanya peningkatan kompetensi account officer syariah akan mengurangi resiko pembiayaan dalam menjalankan pembiayaan mudharabah di lembaga keuangan mikro syariah, begitu juga sebaliknya bila kompetensi account officer syariah menurun maka resiko akan semakin besar.

\section{$>$ Uji Signifikansi}

Berdasarkan hasil pengujian secara parsial dapat diketahui bahwa:

Berdasarkan tabel 7 di atas dapat diketahui bahwa tingkat signifikansi dari variabel Kompetensi terhadap variabel resiko pembiayaan yaitu sebesar 0,000. Angka ini lebih kecil dari taraf signifikan 0,05. Hal ini menjelaskan bahwa variabel Kompetensi memiliki pengaruh terhadap variabel resiko pembiayaan. Dengan demikian, maka hipotesis 2 dalam penelitian ini yang menyatakan bahwa Kompetensi account officer syariah berpengaruh terhadap resiko pembiayaan mudharabah diterima.

\section{g. Analisis regresi sederhana resiko terhadap kinerja}

Tabel 8 Regresi sederhana resiko terhadap kinerja

\begin{tabular}{|l|l|l|c|l|l|}
\hline Variabel & $\begin{array}{l}\text { Unstnd.Coef. } \\
\text { (B) }\end{array}$ & $\begin{array}{l}\text { Standar } \\
\text { error }\end{array}$ & T & Sig. & Keterangan \\
\hline (Constant) & 29.406 & 3.287 & 8.947 & 0.000 & \\
\hline Resiko & -.338 & .150 & -2.255 & 0.031 & Signifikan \\
\hline
\end{tabular}

Adjusted $\mathrm{R}^{2}$ Square $=0,105$ $\mathrm{e}=0,81$

Berdasarkan perhitungan analisis regresi berganda di atas, diketahui bahwa besarnya R Adjusted Square adalah 0,105. Hal ini berarti 10,5\% variasi naik turunnya kinerja pembiayaan mudharabah bisa dijelaskan oleh variasi dari variabel independen (resiko pembiayaan). Sedangkan sisanya $(100 \%-10,5 \%=89,5 \%)$ dijelaskan oleh sebab-sebab yang lain diluar model penelitian. Berdasarkan dari nilai Adjusted R Square dapat diartikan pula kompetensi mampu mempengaruhi resiko sebesar 10,5\%. Di dalam perhitungan ini juga terdapat standar error (e) sebesar 0,816 yang artinya kemungkinan kesalahan estimasi atau perhitungan dalam penelitian ini sebesar 0,816. Berdasarkan hasil analisis di atas, maka dapat disusun persamaan regresi sebagai berikut :

$$
\mathrm{Y} 1=-0,338 \mathrm{X} 1+0,816
$$

Berdasarkan persamaan regresi di atas, maka dapat dijelaskan sebagai berikut: 
1. Koefisien regresi resiko bernilai Negatif sebesar - 0,338, hal ini menunjukkan resiko berpengaruh secara terbalik, sehingga adanya penurunan resiko pembiayaan mudharabah akan meningkatkan kinerja pembiayaan mudharabah.

\section{$>$ Uji Signifikansi}

Berdasarkan hasil pengujian secara parsial dapat diketahui bahwa:

Berdasarkan tabel 4.11 di atas dapat diketahui bahwa tingkat signifikansi dari variabel Kompetensi terhadap variabel resiko pembiayaan yaitu sebesar 0,031. Angka ini lebih kecil dari taraf signifikan 0,05. Hal ini menjelaskan bahwa variabel resiko pembiayaan mudharabah memiliki pengaruh terhadap variabel kinerja pembiayaan mudharabah. Dengan demikian, maka hipotesis 3 dalam penelitian ini yang menyatakan bahwa resiko pembiayaan mudharabah berpengaruh terhadap kinerja pembiayaan mudharabah diterima.

\section{h. Uji Intervening}

Agar dapat membuktikan bahwa variabel resiko pembiayaan mampu menjadi variabel yang memediasi antara kompetensi terhadap kinerja pembiayaan mudharabah, maka dilakukan perhitungan pengaruh langsung dan tidak langsung antara kompetensi terhadap kinerja. Untuk melakukan perhitungan secara langsung dan tidak langsung dilakukan dari nilai standardized coeffients regresi masing-masing variabel independen terhadap variabel dependen dan dapat dibuat gambar analisis jalur.

\section{Gambar 1}

\section{Analisis Intervening Kompetensi Terhadap Kinerja Melalui} resiko pembiayaan

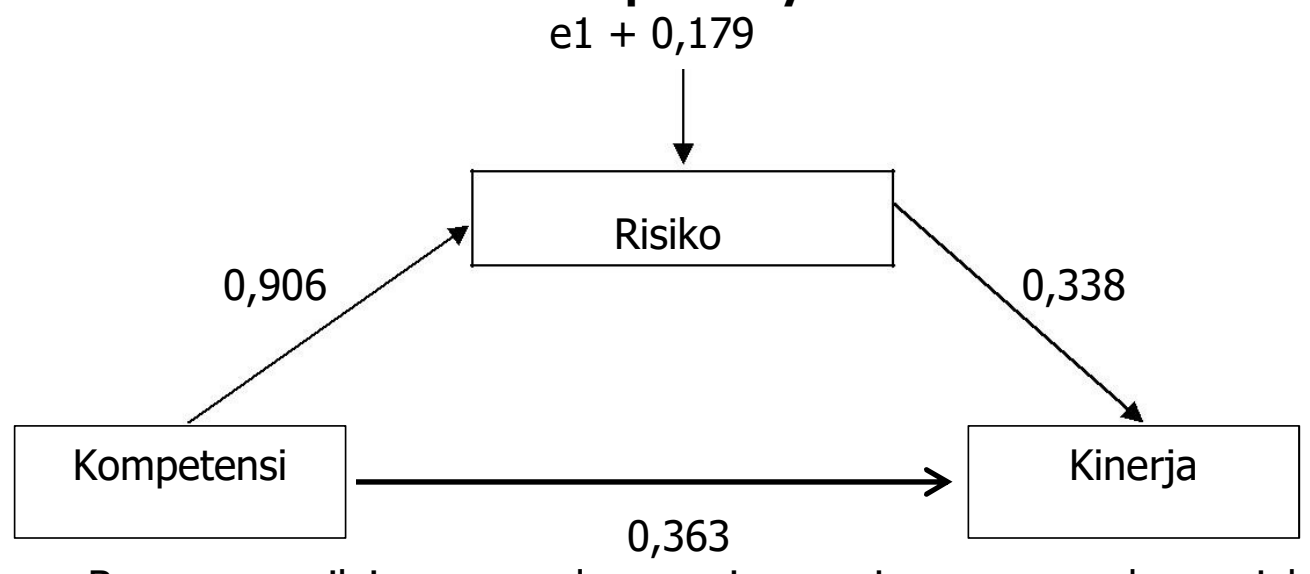

Besarnya nilai errorpada masing-masing pengaruh variabel independen terhadap dependen di dapat melalui perhitungan sebagai berikut:

$$
\begin{aligned}
& \text { Pe1 }=0,179 \\
& \text { Pe2 }=-0,547
\end{aligned}
$$

Dalam teori trimming pengujian validitas model riset diamati melalui perhitungan koefesien determinasi total sebagai berikut: 


$$
\begin{array}{ll}
= & 1-(0,179)^{2} \cdot(-0,547)^{2} \\
= & 0.99
\end{array}
$$

Nilai koefisien determinasi sebesar $99 \%$ menunjukkan bahwa $99 \%$ informasi yang terkandung dalam data dapat dijelaskan oleh model, sedangkan sisanya sebesar $1 \%$ dijelaskan oleh error dan variabel lain di luar model. Angka koefesien pada model ini relatif besar sehingga layak dilakukan interprestasi lebih lanjut. Pada gambar analisis jalur memperlihatkan pengaruh langsung kompetensi terhadap kinerja sebesar 0,363 . Sementara pengaruh tidak langsung melalui resiko pembiayaan yaitu $0,906 \times 0,338=0,306$. Dan pengaruh secara total dari kompetensi account officer syariah terhadap kinerja pembiayaan mudharabah dengan resiko pembiayaan sebagai variabel intervening adalah 0,363 $+0,306=$ 0,669 .

\section{Pengaruh Kompetensi Account officer Syariah Terhadap Kinerja Pembiayaan Mudharabah.}

Berdasarkan hasil penelitian membuktikan bahwa variabel kompetensi account officer syariah memiliki pengaruh signifikan terhadap kinerja pembiayaan mudharabah. Artinya semakin tinggi kompetensi account officer syariah, maka diharapkan kualitas kinerja pembiayaan mudharabah akan semakin baik. Hasil penelitian ini sejalan dengan hasil penelitian yang dilakukan oleh Achmad Iswahyudi (2013), Emmyah (2009), Wei and Weidong (2002), Ismail (2001), Ibrahim (2004), Yumanita (2005), Samad dan Hasan (1999), Thaher dan Abdul (2004), Fry and Matherly (2003) yang menunjukkan bahwa kompetensi account officer syariah memiliki pengaruh terhadap kinerja pembiyaan mudharabah.

Kompetensi yang dimiliki oleh account officer dalam bentuk gabungan karakteristik pengetahuan (knowledge), keterampilan (skill), dan sikap atau perilaku atau kualitas pribadi (attiude) sebagai gabungan karakteristik akan berdampak berfungsi dalam melakukan kebiasaan atau dalam menghadapi situasi tertentu. Hal ini akan mempengaruhi account officer syariah terhadap kinerja dari pembiayaan mudharabah yang dilaksanakan oleh koperasi syarih, BMT atau kapontren dan lembaga keuangan mikro syariah.

Untuk memiliki kompetensi yang tinggi, serangkaian pelatihan sangat diperlukan oleh seorang account officer. Baik itu secara personal ataupun secara organisasional. Pelatihan yang dilaksanakan oleh organisasi diharapkan dapat meningkatkan Pemahaman dan pengetahuan yang memadai mengenai pembiayaan mudharabah sebagai seorang account officer syariah sehingga mampu meningkatkan kinerja dari pembiayaan mudharabah itu sendiri.

\section{Pengaruh Kompetensi Account officer Syariah Terhadap Resiko Pembiayaan Mudharabah.}


Berdasarkan hasil penelitian membuktikan bahwa variabel kompetensi account officer syariah memiliki pengaruh signifikan terhadap resiko pembiayaan mudharabah. Artinya semakin tinggi kompetensi account officer syariah, maka diharapkan pengendalian terahadap kualitas resiko pembiayaan mudharabah akan semakin baik. Hasil penelitian ini sejalan dengan hasil penelitian yang dilakukan oleh Achmad Iswahyudi (2013), Wardayanti (2013), Karim (2004).

Kompetensi yang dimiliki oleh account officer dalam bentuk gabungan karakteristik akan berfungsi dalam melakukan kebiasaan dalam penangan terhadap berbagai bentuk resiko pembiayaan mudharabah. Kompetensi account officer dibutuhkan untuk mencegah resiko yang tidak diingikan, oleh sebab itulah, kompetensi account officer sangat berpengaruh kuat terhadap resiko pembiayaan mudharabah.

Kompetensi yang tinggi dalam mengendalikan resiko, dibutuhkan serangkaian pelatihan oleh seorang account officer. Baik itu secara personal ataupun secara organisasional. Pelatihan yang dilaksanakan oleh organisasi diharapkan dapat meningkatkan pemahaman dan pengetahuan yang memadai mengenai resiko pembiayaan mudharabah sebagai seorang account officer syariah sehingga mampu mengendalikan resiko dari pembiayaan mudharabah itu sendiri.

\section{Pengaruh Resiko Pembiayaan Mudharabah Terhadap Kinerja Pembiayaan Mudharabah.}

Berdasarkan hasil penelitian membuktikan bahwa variabel resiko memiliki pengaruh signifikan terhadap kinerja pembiayaan mudharabah. Artinya semakin baik memahami dan mengendalikan resiko, maka diharapkan kualitas kinerja pembiayaan mudharabah akan semakin baik. Hasil penelitian ini sejalan dengan hasil penelitian yang dilakukan oleh Achmad Iswahyudi (2013), Emmyah (2009), Wei and Weidong (2002), Ismail (2001), Ibrahim (2004), Yumanita (2005), Samad dan Hasan (1999), Thaher dan Abdul (2004), Fry and Matherly (2003) yang menunjukkan bahwa resiko memiliki pengaruh terhadap kinerja pembiyaan mudharabah.

Pelatihan account officer tentang penanganan dan pemahan resiko pembiayaan syariah akan berdampak dalam melakukan kebiasaan atau dalam menghadapi situasi tertentu. Hal ini akan mempengaruhi resiko terhadap kinerja dari pembiayaan mudharabah yang dilaksanakan oleh koperasi syarih, BMT atau kapontren dan lembaga keuangan mikro syariah.

Untuk memiliki kemampuan mengendalikan resiko, serangkaian pelatihan sangat diperlukan oleh seorang account officer. Baik itu secara personal ataupun secara organisasional. Pelatihan yang dilaksanakan oleh organisasi diharapkan dapat meningkatkan Pemahaman dan pengetahuan yang memadai mengenai pemahaman resiko sehingga mampu meningkatkan kinerja dari pembiayaan mudharabah itu sendiri. 


\section{Pengaruh Kompetensi Account officer Syariah Terhadap Kinerja Pembiayaan Mudharabah Melalui Resiko Pembiayaan Mudharabah.}

Hasil analisis regresi menunjukkan variabel bebas yaitu kompetensi account officer dan resiko pembiayaan mudharabah tidak berpengaruh secara langsung terhadap kinerja pembiayaan mudharabah tetapi resiko pembiayaan mudharabah memiliki pengaruh terhadap kinerja pembiayaan muharabah. Hal ini menunjukan kesesuaian dengan kenyataan yang terjadi di lapangan, kinerja pembiayaan syariah dipengaruhi oleh resiko pembiayaan mudharabah. Semakin kecil resiko pembiayaan mudharabah, maka semakin tinggi kinerja pembiayaan mudharabah. Begitu juga kompetensi account officer berpengaruh terhadap resiko pembiayaan mudharabah. Semakin tinggi kompetensi account officer, maka resiko pembiayaan mudharabah semakin kecil.

Hal ini sesuai penelitian yang dilakukan oleh wardayanti (2013) dan iswahyudi (2013) yang mengatakan terdapat pengaruh kompetensi account officer terhadap resiko pembiayaan mudharabah dan berpengaruh secara langsung terhadap kinerja pembiayaan mudharabah.

Berpengaruhnya account officer syariah dalam hal ini dikarenakan pengetahuan (knowledge), keterampilan (skill), dan sikap atau perilaku atau kualitas pribadi (attiude) akan berdampak terhadap kinerja pembiayaan mudharabah. Demikian pula dengan resiko pembiayaan mudharabah akan mempengarui kinerja pembiayaan mudharabah dengan adanya beberapa indikator dari resiko pembiayaan mudharabah yang diukur dengan resiko bisnis yang dibiayai, resiko berkurangnya nilai pembiayaan mudharabah, resik karakter buruk mudharib dan resiko yang timbu dari lemahnya analisis account officer.

Kompetensi account officer syariah mempengaruhi secara langsung terhadap kinerja pembiayaan mudharabah, serta berpengaruh juga terhadap resiko pembiayaan mudharabah. Hal ini sesuai dengan hasil dari Uji Intervening yang dianalisis menggunakan SPSS, kompetensi account officer dapat mempengaruhi secara langsung sebesar 0,363 terhadap kinerja pembiayaan mudharabah dan memliki pengaruh melalui resiko pembiayaan mudharabah sebesar 0,306.

\section{CONCLUSION, IMPLICATION, AND LIMITATION}

Simpulan dari penelitian mengenai pengaruh kompetensi terhadap kinerja dengan resiko sebagai variabel intervening pada lembaga keuangan mikro syariah di pulau Lombok adalah sebagai berikut:

1. Kompetensi berpengaruh positif dan signifikan terhadap kinerja, sehingga adanya peningkatan kompetensi account officer syariah akan meningkatkan kinerja pada pembiayaan mudharabah.

2. Kompetensi berpengaruh negative dan signifikan terhadap resiko pembiayaan mudharabah. Semakin tinggi kompetensi, maka 
resiko pembiayaan mudharabah itu semakin kecil.

3. Resiko pembiayaan mudharabah berpengaruh negative dan signifikan terhadap kinerja pembiayaan mudharabah. Semakin kecil resiko, kinerja pembiayaan mudharabah akan semakin baik.

4. Kompetensi tidak mempunyai pengaruh tidak langsung terhadap kinerja pembiayaan melalui resiko pembiayaan, tetapi kompetensi mempunyai pengaruh terhadap resiko pembiayaan mudharabah. sehingga dapat disimpulkan bahwa semakin tinggi kompetensi seorang account officer, dapat mengurangi resiko pembiayaan mudharabah.

Penelitian ini juga masih memiliki keterbatasan-keterbatasan. Dengan keterbatasan ini diharapkan dapat dijadikan untuk melakukan perbaikan pada penelitian mendatang. Adapun keterbatasan penelitian ini adalah karena yang menjadi responden adalah pimpinan, sehingga informasi yang diperoleh melalui wawancara sangat terbatas karena pimpinan lebih banyak tidak berada di tempat. Untuk penelitian selanjutnya dapat menggunakan tingkatan karyawan lain untuk mengetahui informasi yang lebih banyak. Selian itu, sampel yang $h$ anya dilakukan pada lembaga keuangan mikro syariah sehingga analisis pembiayaan mudharabah hanya dilihat dari system pada lembaga keuangan mikro syariah.

Penelitian selanjutnua disarankan untuk (1) memperluas populasi penelitian tidak hanya sebatas lembaga keuangan mikro syariah saja, tetapi masuk kepada bank swasta dan bank pemerintah yang berbasis syariah. (2) variable yang di teliti dapat lebih diperluas lagi. Misalnya saja dengan melihat dari sisi konsumen, peraturan pemerintah, pendidikan masyarakat, agama ataupun lainnya (3) Untuk lembaga keuangan mikro syariah, kompetensi account officer sangat berperan penting dalam meningkatkan kinerja pembiayaan mudharabah dan berpengaruh terhadap resiko pembiayaan mudharabah. Sehingga, sebaiknya yang memegang posisi sebagai manajer di pembiayaan mudharabah adalah orang yang berkompeten di bidangnya.

\section{REFERENCES}

Ahmed, Habib, 2005. Operational Structure for Islamic Equity Finance. Paper 69: 1-40. Jeddah Saudi Arabia: Islamic Development Bank Islamic Research And Institute.

Antonio, Muhammad Syafi'i, 2001. Bank Syariah : Dari Teori ke Praktek. Jakarta:Gema Insani.

Arifin, Zainul, 2006. Dasar-Dasar Manajemen Bank Syari'ah. Jakarta: Pustaka Alvabet.

Bank Indonesia, 2000. Potensi, Preferensi dan Perilaku Masyarakat Terhadap Bank Syariah: Studi Pada Wilayah Jawa Timur. http://www.bi.go.id./ 
El-Biraika, Adam, 2001. The 1997-1998 East Asian Financial Crises, an Islamic perspective. Working Paper Economic Research Forum. United Arab: Emirab University.http//www.econpapers.repec.org/

Emmyah, 2009. Pengaruh Kompetensi Terhadap Kinerja Pegawai pada Politeknik Negeri Ujung Pandang. http://www.google.com.

Ghozali, Imam. 2005. Aplikasi Analisis Multivariate Dengan Program SPSS. Badan Penerbit Universitas Diponegoro: Semarang

Ibrahim, Maulana, 2004. Risk Management: Islamic Financial Policies : Case Study of Bank Indonesia. http://www.bi.go.id.

Iqbal, Munawar, 2001. Islamic and Conventional Banking in the Nineties: a Comparative Study. Journal of Islamic Economic Studies $8(2): 1-28$.

Karim, Adiwarman, 2004(a). Bank Islam: Analisis Fiqih dan Keuangan. Edisi Kedua, Jakarta: PT. Raja Grafindo Persada.

Muhammad, 2008. Manajemen Pembiayaan Mudharabah di Bank Syariah. Jakarta:Rajawali

, 2000. Lembaga Keuangan Umat Kontemporer. Yogyakarta:UII Press

Rivai, Veithzal dan Andria permata veithzal, Islamic finance managemen, Jakarta: PT. RajaGrafindo, 2006.

Soenarjo, 1971.Quran dan terjemahan.Jakarta:Yayasan penterjemah alquran Indonesia

Wei, Zhang and Zhong Weidong, 2002. College Student's Performance Appraisal Based on Profesional Competency: an Example of Human ResourceManagement. Business Management Postdoctoral Mobile Station. Xiamen University.

Yumanita, Ascarya Diana, 2005. Mencari Solusi Rendahnya Pembiayaan Bagi-

Hasil Di Perbankan Syari'ah Indonesia. Buletin Ekonomi Moneter dan Perbankan : 8-50. Jakarta: Bank Indonesia. http//www.bi.go.id/ 